\title{
Surface Equilibrium Angle for Anisotropic Grain Growth and Densification Model in Ceramic Materials
}

\author{
Sergio Cava ${ }^{1}$, Sergio M. Tebcherani ${ }^{2}$, Sidnei A. Pianaro ${ }^{2}$, \\ Elson Longo ${ }^{3}$ and José A. Varela ${ }^{3}$ \\ ${ }^{1}$ Universidade Federal de Pelotas \\ ${ }^{2}$ Universidade Estadual de Ponta Grossa \\ ${ }^{3}$ Universidade Estadual Paulista \\ Brazil
}

\section{Introduction}

Sintering is the main operation in powder technology. This explains the attention of scientists and practical engineers towards sintering.

Currently there are two main cardinally different approaches to describing sintering: classical physical sintering theory and phenomenological. The first rests on physical constants at the level of individual particles, and the second is based on continuum equations for solid (viscous medium) mechanics, and it requires for its implementation presence of empirical coefficients and it is used for describing macroscopic problems of powder technologyGalakhov (2009).

Experimentally, the most common way to investigate the relative energy of the grain boundary consist in establishing a relationship of the surface free energy of the material with its grains geometryJin et al. (2000); Kinderlehrer et al. (2002); Xin \& Wong (2003). This relationship was firstly quantified by HerringHerring (1951) who found out that the surface free energy is stationary when the balance process is reached. In this way, it is possible to determine the whole interface energy by observing the geometry of a certain number of interfaces among crystals of well-known orientation.

Thus, the flow of atoms $j_{a}$ of a system is related to the intrinsic diffusion coefficient $D$ and the gradient of chemical potential difference between the atom and the vacancy, in accordance with the Herring equation Herring (1950).

$$
j_{a}=-\frac{D}{\Omega_{a} k_{B} T} \nabla\left(\mu_{a}-\mu_{v}\right)
$$

where $\frac{D}{k_{B} T}$ represent the relative term of material mobility through the grain boundary or diffusion by the lattice, $k_{B}$ is the Boltzman constant, $T$ is an absolute temperature, $\Omega_{a}$ is the atomic volume, $\mu_{a}$ and $\mu_{v}$ are the chemical potentials of atom and vacancies, $\nabla\left(\mu_{a}-\mu_{v}\right)$ is the gradient between the chemical potentials difference that leads to the mass transport. 
In a general way, Hansen et al. (1992) has obtained a relationship denominated as a flow general equation:

$$
j_{a s}=\frac{D}{k_{B} T}\left(\frac{\alpha \gamma C_{k}}{C_{\lambda} G^{2}}\right)
$$

where: $\alpha$ is a proportionality constant that relates the gradient with $\lambda$ and is just dependent of the three-dimensional geometric relationship between sources and material drains along the limit of the grain boundary, being $\lambda$ the linear average distance of defined diffusion for the intersection between a pore and the center of the neck among two grains, $\gamma$ is the surface energy, $G$ is the average grain diameter, $C_{k}$ and $C_{\lambda}$ are geometric proportionality constants where $K$ defines the medium curvature of pore.

In surface techniques, the excess of the grain boundary free energy per surface free energy $\left(\gamma_{g b} / \gamma_{S}\right)$ Dhalenne et al. (1983); Kingery (1994); Moment \& Gordon (1964); Readey \& Jech (1968); Shackelford \& Scott (1968); Wolf (1983) is a function of the dihedral angle of experimental surface measured by the intersection $\Psi_{S}$ giving the equation:

$$
\frac{\gamma_{g b}}{\gamma_{S}}=2 \cos \frac{\Psi_{S}}{2}
$$

The determination of materials structures in polycrystals ceramics with high surface area are being facilited microscopy techniquesMunoz et al. (2004); Saylor et al. (2000); Saylor \& Rohrer (1999). The liquid phase formed during sintering process is found by means of determination of dihedral angleBelousov $(2003 ; 2004)$.

Under appropriate experimental conditions, surface dihedral angles, relative grain boundary energies, and surface diffusivities determined from Atomic Force Microscopic (AFM) measurements are consistent with data acquired by more laborious techniquesSaylor \& Rohrer (1999).

The densification equations for pressure less solid state sintering can be easily extended to describe the densification behavior during hot-pressing or hot-isostatic-pressingBeeman \& Kohlstedt (1993); Shi (1999).

In this paper the use of the AFM technique to determine the dihedral surface angle for compacts sintered in solid-phase with anisotropic grain growth of $0.5 \mathrm{Mol} \% \mathrm{MnO}_{2}$-doped tin dioxide obtained by the chemical method of the polymeric precursor is described.

\section{Experimental procedure}

The polymeric precursor solution was prepared by the Pechini method, which has been used to synthesize polycationic powders Cassia-Santos et al. (2005); Cava, Sequinel, Berger \& Tebcherani (2009); Cava, Sequinel, Tebcherani, Michel, Lazaro \& Pianaro (2009); Cava et al. (2006; 2007); de Lucena et al. (2005); Gonzalez et al. (2004); Pontes et al. (2004); Simoes et al. (2004); Simoes, Ramirez, Perruci, Riccardi, Longo \& Varela (2005); Simoes, Ramirez, Riccardi, Ries, Longo \& Varela (2005); Simoes, Ries, Moura, Riccardi, Longo \& Varela (2005). The process is based on the metallic citrate polymerization using ethylene glycol. A hydrocarboxylic acid, such as citric acid, is used to chelate cations in an aqueous solution. The addition of a glycol such as ethylene glycol leads to the formation of an organic ester. Polymerization, promoted by heating the mixture, results in a homogeneous resin in which metal ions are uniformly distributed throughout the organic matrix. 
In the experiments, tin chloride dehydrated $\mathrm{SnCl}_{2} \cdot 2 \mathrm{H}_{2} \mathrm{O}$ (Merck) was first dissolved in distilled water. Subsequently ammonium hydroxide - $\mathrm{NH}_{4} \mathrm{OH}$ (Synth) was added in order to form tin hydroxide - $\mathrm{Sn}(\mathrm{OH})_{2}$ Besso (n.d.), according to equation 4.

$$
\mathrm{SnCl}_{2}+\mathrm{NH}_{4} \mathrm{OH} \rightarrow \mathrm{Sn}(\mathrm{OH})_{2}+\mathrm{NH}_{4} \mathrm{Cl}
$$

The presence of chloride in the solution was analyzed after decantation by means of the addition of silver nitrate in the filtrate liquid. Due to the silver chloride formed as a white solid insoluble in water Baccan et al. (1990) it is possible to predict the absence of $\mathrm{Cl}^{-}$within tolerance limit for the following equation.

$$
\mathrm{Ag}_{(a q)}^{+}+\mathrm{Cl}^{-} \rightarrow \mathrm{AgCl}_{(s)}
$$

With the controlled addition of citric acid anhydrous $-\mathrm{C}_{6} \mathrm{H}_{8} \mathrm{O}_{7}$, dissolved at $50^{\circ} \mathrm{C}$ for $1 \mathrm{~h}$, the formation of tin citrate took place. The citric acid/metal molar ratio was fixed at 3:1.

Manganese acetate (Carlo Erba) was added at $0.5 \mathrm{~mol} \%$ to obtain the doped compositions 0.5 $\mathrm{Mol} \% \mathrm{MnO}_{2}$-doped tin dioxide. The polymerization occurred upon the addition of ethylene glycol $-\mathrm{C}_{2} \mathrm{H}_{6} \mathrm{O}_{2}$. The mass ratio of the citric acid/ethylene glycol was set at 60:40.

This mixture was then stirred at $80^{\circ} \mathrm{C}$ for $1 \mathrm{~h}$ until the solution became completely transparent. This solution was further heated at $130^{\circ} \mathrm{C}$ to promote polymerization and remove excess solvents.

The powder obtained was heat-treated in an oxygen atmosphere at $400^{\circ} \mathrm{C}$ for 4 hours, in order to oxidate the remaining organic matter. The powder obtained in this way is referred to as the "precursor". In the furnace, the precursor was heat-treated at the $600^{\circ} \mathrm{C}$ during 15 hours, in an $\mathrm{Al}_{2} \mathrm{O}_{3}$ boat, and then cooled to room temperature.

This obtained powder was compacted by uniaxial pressing (SCHWING SIWA-15T) using pressure of $15 \mathrm{MPa}$ followed by isostatic pressing (CARLZEISS-JENA) using pressure of 210 MPa forming cylindrical disks of approximately $6.0 \mathrm{~mm}$ of diameter and $6.0 \mathrm{~mm}$ of height, where the green density reached $60 \%$ of the theoretical density. The sintering process was performed in a dilatometer (NETZSCH 402E) using a constant heating rate of $2.5^{\circ} \mathrm{C} / \mathrm{min}$ under atmosphere of synthetic air, reaching the final temperature of $1350^{\circ} \mathrm{C}$ and soak time ranging from 30-120 minutes.

The disks of sintered $0.5 \mathrm{Mol} \% \mathrm{MnO}_{2}$-doped tin dioxide were observed by Transmission Electronic Microscopy (TEM) employing a Philips CM200 equipment.

A standard procedure for TEM sample preparation starting from bulk samples which included cutting, grinding and dimpling was used.

Atomic force microscopy (AFM) was used to obtain an accurate analysis of the sample surface and the quantification of very important parameters such as roughness and average grain size. A Digital Instruments Multimode Nanoscope IIIa (Santa Barbara, CA) was used. AFM imaging was carried out in the contact mode, using a triangular-shaped $200-\mu \mathrm{m}$ long cantilever with a spring constant of $0.06 \mathrm{~N} / \mathrm{m}$.

\section{Results}

The curves of linear shrinkage and shrinkage rate are depicted in the Fig. 1. By means of this analysis it was possible to verify that the $0,5 \mathrm{Mol} \%$ manganese doping in tin dioxide is a sufficient amount to obtain sintered samples with densification closer to theoretical densitiy $(25 \%)$. The derivative of the curve represents a sintering in solid phase without chemical substance transformation. 


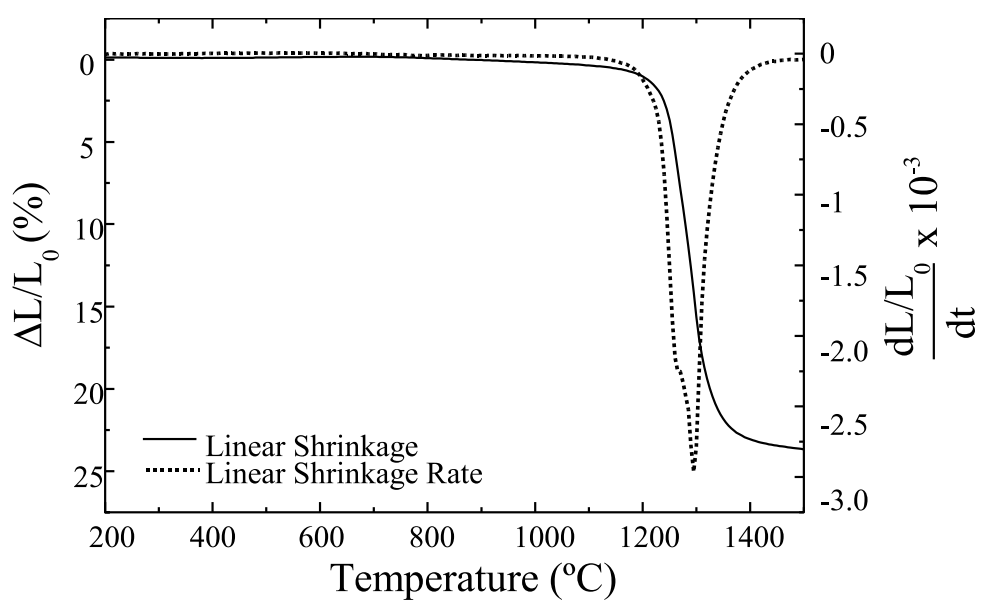

Fig. 1. Linear shrinkage and shrinkage rate of the sintered $0.5 \mathrm{Mol} \% \mathrm{MnO}_{2}$-doped tin dioxide samples.

The sintered tin dioxide tend to form an equilibrium angle of $120^{\circ}$ in the bulk interior due to the vectorial action of the resultants in agreement with the micrograph of transmission electronic microscopy of the Fig. 2

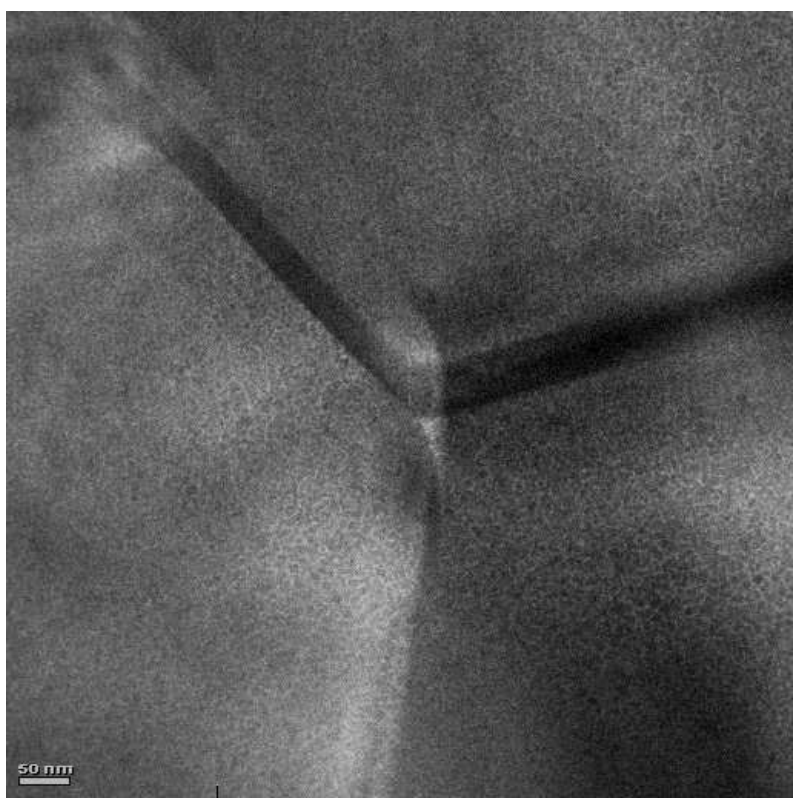

Fig. 2. Micrograph of transmission electronic microscopy of sintered sample of $0.5 \mathrm{Mol} \%$ $\mathrm{MnO}_{2}$-doped tin dioxide.

By means of atomic force microscopy (AFM) an accurate analysis of the interaction among the grains, surface roughness and porosity was obtained, according to Fig 3. 


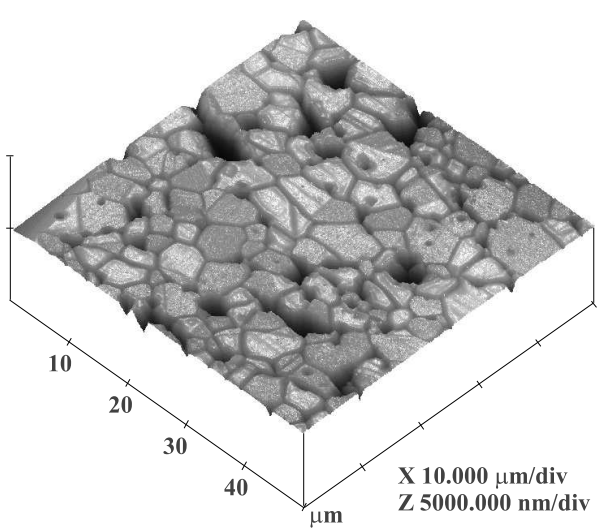

(a)

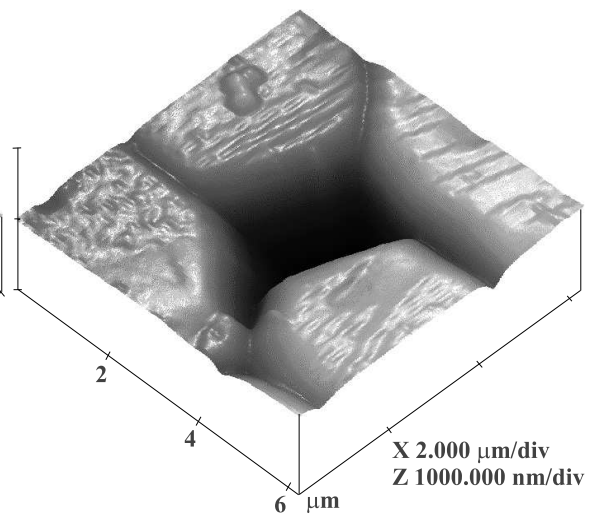

(b)

Fig. 3. AFM micrographs of the sintered $0.5 \mathrm{Mol} \% \mathrm{MnO}_{2}$-doped tin dioxide samples. Soak time of (a) 30 minutes, (b) 50 minutes, indicating the pore detail.

Data of dihedral angles was obtained by means of AFM using procedures of section analysis, according to Fig. 4. An imaginary line is inserted under the micrograph by means of a cursor (indicated by an arrow in the Fig. 4a). The porosity and dihedral angles are determined when the cursor moves along the line. The dihedral angle was determined by extracting and adding, two adjacent angles were subtracted from $180^{\circ}$.

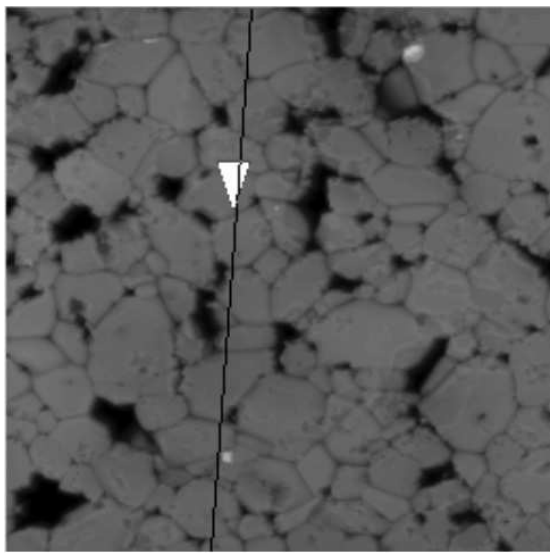

(a)

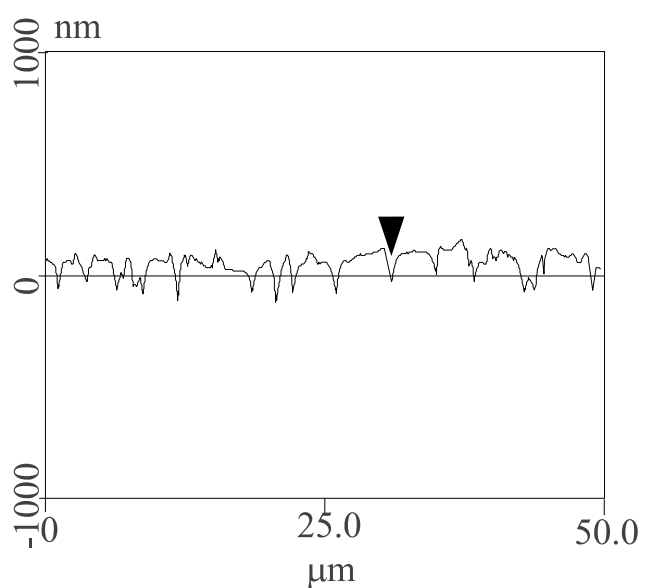

(b)

Fig. 4. Determination of dihedral angle and porosity by AFM. a) Micrograph with imaginary line and lecture cursor represented by an arrow. b) Representation of the cross-section attained by the cursor.

In this way, the obtained dihedral angles are of statistic significance. An average of 300 angles per sample was considered in order to obtain a more precision value $\left( \pm 2.1^{\circ}\right)$. Thus, the dihedral angles are changed when the soak time is raised, in accordance with Fig. 5. 


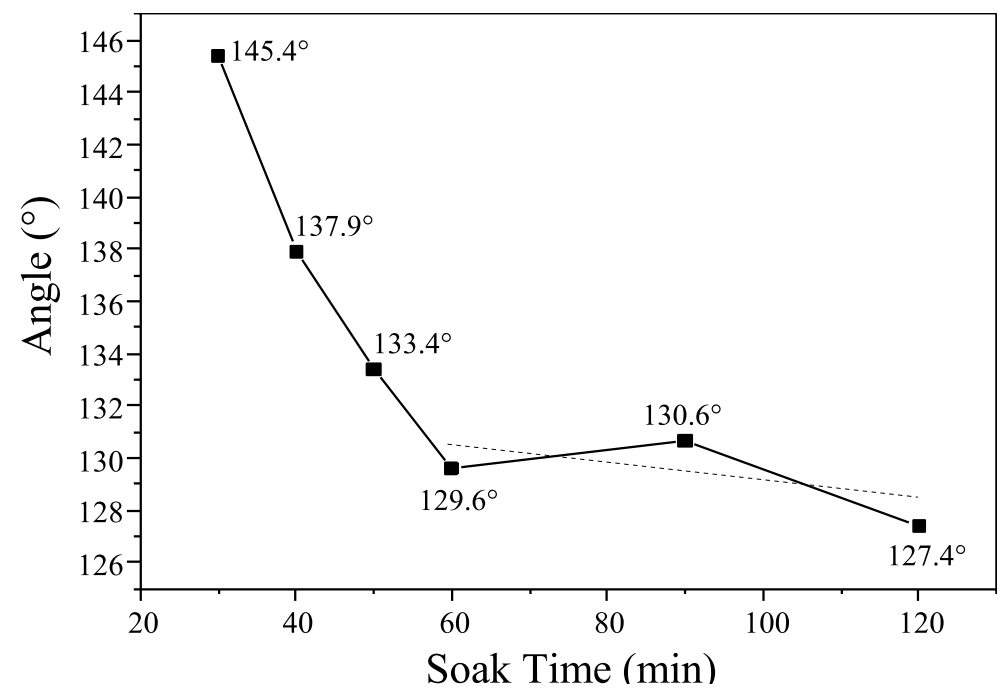

Fig. 5. Angular evolution according to the time required to reach the equilibrium angle. $\mathrm{SnO}_{2} \cdot 0.5 \mathrm{Mol} \% \mathrm{MnO}_{2}$. AFM Dihedral angle Thermal treatment. $\mathrm{Er}= \pm 1.38$. FFT linear $=$ $129.22^{\circ}$

With the soak time ranging from 30 up to 120 minutes, the angle is decreased from $145^{\circ}$ to $129^{\circ}$. However, the angle remain practically constant around $129.22^{\circ}\left( \pm 1.38^{\circ}\right)$ for thermal treatment with soak times higher than 60 minutes. In this way, the dihedral equilibrium angle was determined.

This process is due to the migration of the manganese to the surface of tin dioxide caused by the higher temperature of thermal treatment. The exudation causes disequilibrium in the vectorial composition among the interfaces energy. Consequently, the chemical potential of $\mathrm{SnO}_{2}$ grain boundaries is reduced as a attempt to return at the equilibrium.

The equilibrium of the grain growth in the surface is attained through thermal treatment with soak time higher than 60 minutes. This process is named as equilibrium dihedral angle.

Tab. 1 shows the number of times (fraction) that the dihedrals angles was extracted from AFM micrographs in function of the values of those angles and, for each thermal treatment. The angles were counted at each $10^{\circ}$ starting from $90^{\circ}$ up to $160^{\circ}$. In this way, the frequency in each angular interval was determined.

Fig. 6 was plotted from results of Tab. 1 by means of Gaussian fitting. In this plot, the angular fraction appearances (in percentage) is a function of the angular intervals obtained by AFM micrographs.

A displacement of the plots was made in order to verify the effect of manganese migration into the $\mathrm{SnO}_{2}$ surface. Thus, the maximum point of each plot was moved to a same point related to the angles axis to evaluate the width at half maximum of each plot. Such width is reduced when the time of thermal attack is increased, in accordance with the Table 2). Consequently, the manganese exudation is more effective and the $\mathrm{SnO}_{2}$ dihedral surface angles became more uniforms along the whole analyzed surface for samples heat treated with soak times higher than 60 minutes.

Thus, by means of Fig. 6 it is possible to observe that the manganese is moved to surface in a homogeneous way related to the time of thermal attack. Furthermore, the 


\begin{tabular}{|c|c|c|c|c|c|c|}
\hline & \multicolumn{5}{|c|}{ Soak time (min) } \\
\hline Angle $\left(^{\circ}\right)$ & 30 & 40 & 50 & 60 & 90 & 120 \\
\hline $90^{\circ}$ & $3 \%$ & $3 \%$ & $2 \%$ & $2 \%$ & $0 \%$ & $2 \%$ \\
\hline $100^{\circ}$ & $3 \%$ & $3 \%$ & $3 \%$ & $3 \%$ & $1 \%$ & $3 \%$ \\
\hline $110^{\circ}$ & $3 \%$ & $3 \%$ & $8 \%$ & $8 \%$ & $8 \%$ & $8 \%$ \\
\hline $120^{\circ}$ & $6 \%$ & $5 \%$ & $19 \%$ & $19 \%$ & $22 \%$ & $23 \%$ \\
\hline $130^{\circ}$ & $24 \%$ & $16 \%$ & $29 \%$ & $29 \%$ & $31 \%$ & $33 \%$ \\
\hline $140^{\circ}$ & $38 \%$ & $33 \%$ & $25 \%$ & $24 \%$ & $25 \%$ & $21 \%$ \\
\hline $150^{\circ}$ & $19 \%$ & $27 \%$ & $11 \%$ & $11 \%$ & $10 \%$ & $6 \%$ \\
\hline $160^{\circ}$ & $4 \%$ & $10 \%$ & $3 \%$ & $4 \%$ & $3 \%$ & $4 \%$ \\
\hline
\end{tabular}

Table 1. Angular fraction corresponding for the soak times.

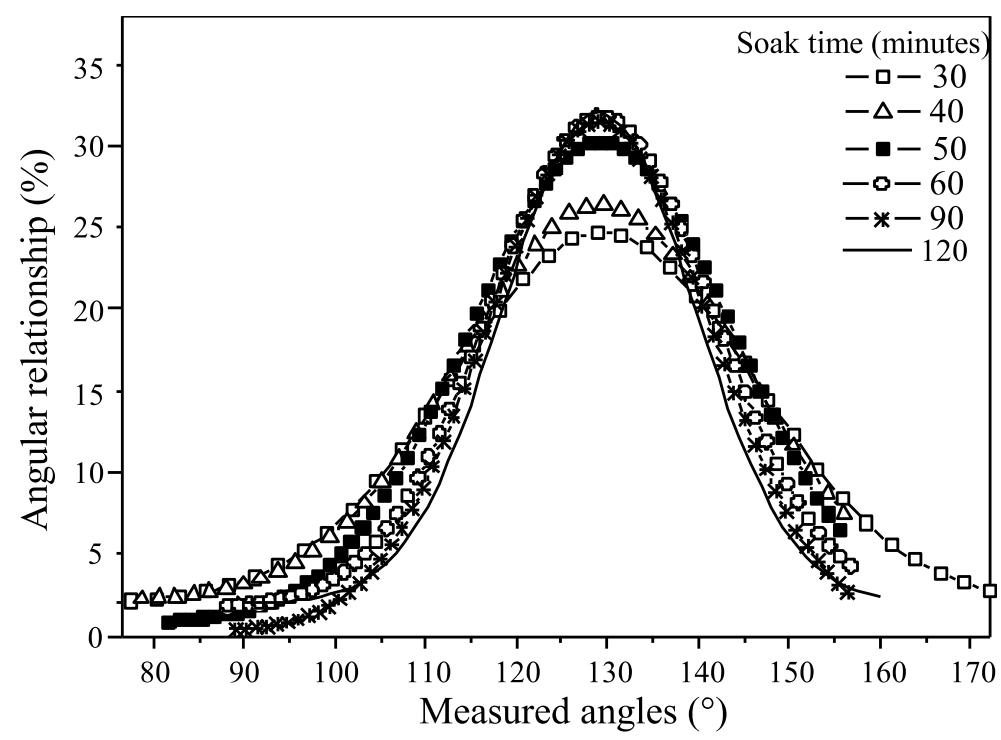

Fig. 6. Gaussian curve of the angular proportion according to the dihedral angles values.

\begin{tabular}{|c|c|}
\hline Soak time (min) & Width at half maximum \\
\hline 30 & $33^{\circ}$ \\
\hline 40 & $27.3^{\circ}$ \\
\hline 50 & $28.3^{\circ}$ \\
\hline 60 & $24.9^{\circ}$ \\
\hline 90 & $24^{\circ}$ \\
\hline 120 & $24.3^{\circ}$ \\
\hline
\end{tabular}

Table 2. Angular difference of width at half maximum related to the soak time. 
appearing frequency of the $\mathrm{SnO}_{2}$ dihedral angles in the surface is also related to the time and temperature.

\section{Conclusion}

The tin dioxide doped with a densifier agent, such as $\mathrm{MnO}_{2}$, has a high energy gradient in the external surface when sintered. The observed grain growth is an indicative that the surface is affected by the thermal treatment. SEM micrographs showed the manganese exudation effect on the surface when the sample was heated at optimized conditions. This manganese migration at the surface led to a new grain growth in the extenal surface of the sample due to the gradient in the potential energy surface. The temperature influenced by the dynamic geometry of the oxide surface was characterized by AFM analysis. Also, this is true for anisotropic grain growth, such as in this case of $\mathrm{SnO}_{2}$. This grain growth originated in the oxide surface is only stopped when a new angular equilibrium is stablished. In this way, a relationship between time of thermal attack and formation of a new surface equilibrium can be obtained. This process is named as equilibrium dihedral angle.

\section{Acknowledgments}

The authors gratefully acknowledge the financial support of the Brazilian financing agencies PIBIC/CNPq and Paraná Tecnologia.

\section{References}

Baccan, N., Aleixo, L., Stein, E. \& Godinho, O. (1990). 3rd edition edn, Unicamp, Campinas.

Beeman, M. L. \& Kohlstedt, D. L. (1993). Deformation of fine-grained aggregates of olivine plus melt at high-temperatures and pressures, J. Geophys. Res.-Solid Earth 98(B4): 6443-6452.

Belousov, V. V. (2003). Wetting of grain boundaries in cuprate ceramics, Inorg. Mater. 39(1): 82-89.

Belousov, V. V. (2004). Wetting of grain boundaries in ceramic materials, Colloid J. 66(2): 121-127.

Besso, M. (n.d.). US Patent No 3123120. 19-10-65.

Cassia-Santos, M. R., Souza, A. G., Soledade, L. E. B., Varela, J. A. \& Longo, E. (2005). Thermal and structural investigation of $\left(\mathrm{Sn}_{1-x} \mathrm{Ti}_{x}\right) \mathrm{O}_{2}$ obtained by the polymeric precursor method, J. Therm. Anal. Calorim. 79(2): 415-420.

Cava, S., Sequinel, T., Berger, D. \& Tebcherani, S. M. (2009). Synthesis and characterization of microspheres composed of $\mathrm{SnO}_{2}$ nanoparticles processed via a chemical route, Powder Technol. .

Cava, S., Sequinel, T., Tebcherani, S. M., Michel, M. D., Lazaro, S. R. \& Pianaro, S. A. (2009). Microstructure of ceramic particles infiltrated into float glass surfaces by high gas pressure impregnation, J. Alloys Compd. doi:10.1016/j.jallcom.2009.05.061: .

Cava, S., Tebcherani, S. M., Pianaro, S. A., Paskocimas, C. A., Longo, E. \& Varela, J. (2006). Structural and spectroscopic analysis of $\gamma-\mathrm{Al}_{2} \mathrm{O}_{3}$ to $\alpha-\mathrm{Al}_{2} \mathrm{O}_{3}-\mathrm{CoAl}_{2} \mathrm{O}_{4}$ phase transition, Materials Chemistry and Physics 97: 102-108.

Cava, S., Tebcherani, S. M., Souza, I. A., Pianaro, S. A., Paskocimas, C. A., Longo, E. \& Varela, J. A. (2007). Structural characterization of phase transition of $\mathrm{Al}_{2} \mathrm{O}_{3}$ nanopowders obtained by polymeric precursor method, Mater. Chem. Phys. 103(2-3): 394-399. 
de Lucena, P. R., Pessoa-Netob, O. D., dos Santos, I. M. G., Souza, A. G., Longo, E. \& Varela, J. A. (2005). Synthesis by the polymeric precursor method and characterization of undoped and $\mathrm{Sn}, \mathrm{Cr}$ and V-doped $\mathrm{ZrTiO}_{4}$, J. Alloy. Compd. 397(1-2): 255-259.

Dhalenne, G., Dechamps, M. \& Revcolevschi, A. (1983). Advances in Ceramics, Americam Ceramic Society, Columbus, OH, chapter Character of grain boundaries, pp. 139-150.

Galakhov, A. V. (2009). Numerical method for simulating sintering, Refractories and Industrial Ceramics 50(3): 191-197.

Gonzalez, A. H. M., Simoes, A. Z., Zaghete, M. A., Longo, E. \& Varela, J. A. (2004). Effect of thermal treatment temperature on the crystallinity and morphology of $\mathrm{LiTaO}_{3}$ thin films prepared from polymeric precursor method, J. Electroceram. 13(1-3): 353-359.

Hansen, J. D., Rusin, R. P., Teng, M. H. \& Johnson, D. L. (1992). Combined-stage sintering model, J. Am. Ceram. Soc. 75(5): 1129-1135.

Herring, C. (1950). Effect of change of scale on sintering phenomena, J. Appl. Phys. 21(4): 301-303.

Herring, C. (1951). The physics of powder metallurgy, McGraw-Hill.

Jin, M. X., Shimada, E. \& Ikuma, Y. (2000). Atomic force microscopy study of surface diffusion in polycrystalline $\mathrm{CeO}_{2}$ via grain boundary grooving, J. Ceram. Soc. Jpn. 108(5): 456-461.

Kinderlehrer, D., Ta'asan, S., Livshits, I. \& Mason, D. E. (2002). The surface energy of mgo: Multiscale reconstruction from thermal groove geometry, Interface Sci. 10(2-3): 233-242.

Kingery, W. D. (1994). J. Am. Ceram. Soc. 77(2): 349-355.

Moment, R. L. \& Gordon, R. B. (1964). Energy of grain boundaries in halite, J. Am. Ceram. Soc. 47(11): 570-573.

Munoz, N. E., Gilliss, S. R. \& Carter, C. B. (2004). Remnant grooves on alumina surfaces, Surf. Sci. 573(3): 391-402.

Pontes, F. M., Leite, E. R., Nunes, M. S. J., Pontes, D. S. L., Longo, E., Magnani, R., Pizani, P. S. \& Varela, J. A. (2004). Preparation of $\mathrm{Pb}(\mathrm{Zr}, \mathrm{Ti}) \mathrm{O}^{-3}$ thin films by soft chemical route, J. European Ceram. Soc. 24(10-11): 2969-2976.

Readey, D. W. \& Jech, R. E. (1968). Energies and grooving kinetics of [001] tilt boundaries in nickel oxide, J. Am. Ceram. Soc. 51(4): 201-\&.

Saylor, D. M., Mason, D. E. \& Rohrer, G. S. (2000). Experimental method for determining surface energy anisotropy and its application to magnesia, J. Am. Ceram. Soc. 83(5): 1226-1232.

Saylor, D. M. \& Rohrer, G. S. (1999). Measuring the influence of grain-boundary misorientation on thermal groove geometry in ceramic polycrystals, J. Am. Ceram. Soc. 82(6): 1529-1536.

Shackelford, J. F. \& Scott, W. D. (1968). Relative energies of [1100] tilt boundaries in aluminum oxide, J. Am. Ceram. Soc. 51(12): 688-\&.

Shi, J. L. (1999). Solid state sintering of ceramics: pore microstructure models, densification equations and applications, J. Mater. Sci. 34(15): 3801-3812.

Simoes, A. Z., Gonzalez, A. H. M., Riccardi, C. S., Souza, E. C., Moura, F., Zaghete, M. A., Longo, E. \& Varela, J. A. (2004). Ferroelectric and dielectric properties of lanthanum-modified bismuth titanate thin films obtained by the polymeric precursor method, J. Electroceram. 13(1-3): 65-70. 
Simoes, A. Z., Ramirez, M. A., Perruci, N. A., Riccardi, C. S., Longo, E. \& Varela, J. A. (2005). Retention characteristics in $\mathrm{Bi}_{3.25} \mathrm{La}_{0.75} \mathrm{Ti}_{3} \mathrm{O}_{12}$ thin films prepared the polymeric precursor method, Appl. Phys. Lett. 86(11): 112909.

Simoes, A. Z., Ramirez, M. A., Riccardi, C. S., Ries, A., Longo, E. \& Varela, J. A. (2005). Influence of temperature on the dielectric and ferroelectric operties of bismuth titanate thin films obtained by the polymeric precursor method, Mater. Chem. Phys. 92(2-3): 373-378.

Simoes, A. Z., Ries, A., Moura, F., Riccardi, C. S., Longo, E. \& Varela, J. A. (2005). Influence of the solution ph on the morphological, structural and electrical properties of $\mathrm{Bi}_{3.25} \mathrm{La}_{0.75} \mathrm{Ti}_{3} \mathrm{O}_{12}$ thin films obtained by the polymeric precursor method, Mater. Lett. 59(22): 2759-2764.

Wolf, D. (1983). Advances in Ceramics, Americam Ceramic Society, Columbus, OH, chapter Character of grain boundaries, pp. 36-43.

Xin, T. H. \& Wong, H. (2003). Grain-boundary grooving by surface diffusion with strong surface energy anisotropy, Acta Mater. 51(8): 2305-2317. 


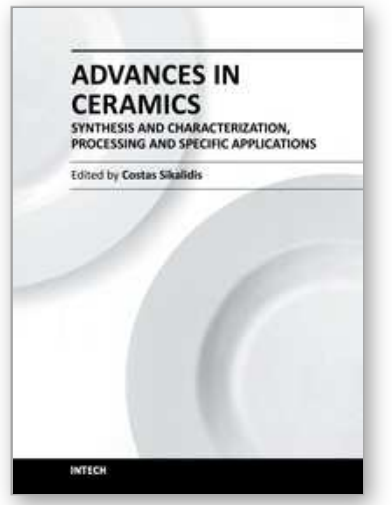

\author{
Advances in Ceramics - Synthesis and Characterization, \\ Processing and Specific Applications \\ Edited by Prof. Costas Sikalidis
}

ISBN 978-953-307-505-1

Hard cover, 520 pages

Publisher InTech

Published online 09, August, 2011

Published in print edition August, 2011

The current book contains twenty-two chapters and is divided into three sections. Section I consists of nine chapters which discuss synthesis through innovative as well as modified conventional techniques of certain advanced ceramics (e.g. target materials, high strength porous ceramics, optical and thermo-luminescent ceramics, ceramic powders and fibers) and their characterization using a combination of well known and advanced techniques. Section II is also composed of nine chapters, which are dealing with the aqueous processing of nitride ceramics, the shape and size optimization of ceramic components through design methodologies and manufacturing technologies, the sinterability and properties of $\mathrm{ZnNb}$ oxide ceramics, the grinding optimization, the redox behaviour of ceria based and related materials, the alloy reinforcement by ceramic particles addition, the sintering study through dihedral surface angle using AFM and the surface modification and properties induced by a laser beam in pressings of ceramic powders. Section III includes four chapters which are dealing with the deposition of ceramic powders for oxide fuel cells preparation, the perovskite type ceramics for solid fuel cells, the ceramics for laser applications and fabrication and the characterization and modeling of protonic ceramics.

\title{
How to reference
}

In order to correctly reference this scholarly work, feel free to copy and paste the following:

Sergio Cava, Sergio M. Tebcherani, Sidnei A. Pianaro, Elson Longo and José A. Varela (2011). Surface Equilibrium Angle for Anisotropic Grain Growth and Densification Model in Ceramic Materials, Advances in Ceramics - Synthesis and Characterization, Processing and Specific Applications, Prof. Costas Sikalidis (Ed.), ISBN: 978-953-307-505-1, InTech, Available from: http://www.intechopen.com/books/advances-in-ceramicssynthesis-and-characterization-processing-and-specific-applications/surface-equilibrium-angle-for-anisotropicgrain-growth-and-densification-model-in-ceramic-materials

\section{INTECH}

open science | open minds

\section{InTech Europe}

University Campus STeP Ri

Slavka Krautzeka 83/A

51000 Rijeka, Croatia

Phone: +385 (51) 770447

Fax: +385 (51) 686166

\section{InTech China}

Unit 405, Office Block, Hotel Equatorial Shanghai

No.65, Yan An Road (West), Shanghai, 200040, China 中国上海市延安西路65号上海国际贵都大饭店办公楼 405 单元

Phone: +86-21-62489820

Fax: +86-21-62489821 
www.intechopen.com 
(C) 2011 The Author(s). Licensee IntechOpen. This chapter is distributed under the terms of the Creative Commons Attribution-NonCommercialShareAlike-3.0 License, which permits use, distribution and reproduction for non-commercial purposes, provided the original is properly cited and derivative works building on this content are distributed under the same license. 